\title{
Airborne fungi spores distribution in various locations in Lagos, Nigeria
}

\author{
Adeyinka Odebode $(\mathbb{D} \cdot$ Adedotun Adekunle • \\ Jason Stajich • Peter Adeonipekun
}

Received: 25 July 2019 / Accepted: 16 December 2019 /Published online: 3 January 2020

(C) The Author(s) 2020

\begin{abstract}
Exposure to outside air microorganisms especially fungi has been linked with illness such as allergic respiratory symptoms, rhinitis, asthma, and infection such as mycosis. Airborne fungal composition was sampled from five locations in Lagos State, Nigeria, between May 2014 and April 2016. Fungi spores were collected using the sedimentation plate method with the Petri dishes of dichloran-glycerol 18 (DG-18) and potato dextrose agar (PDA) media. Fungi sporulated faster on DG-18 agar plate as compared with PDA. The abundances of fungal spores collected monthly at the locations varied. The most abundant spores came from the fungi were Aspergillus niger (14.47\%), Aspergillus sydowii (10.37\%), and Aspergillus flavus (7.93\%). Additional species were present in the collections including Ascomycetes: Penicillium funiculosum (5.49\%), Neurospora crassa $(5.32 \%)$, Penicillium oxalicum (4.71\%), Penicillium pinophilum (2.88\%), Fusarium verticillioides (3.05\%), Penicillium simplicissimum (1.83\%), Aphaderanum sp. (0.22\%), Curvularia sp.
\end{abstract}

A. Odebode $\cdot$ A. Adekunle $\cdot$ P. Adeonipekun

Department of Botany, Faculty of Science, University of Lagos, Akoka, Nigeria

A. Odebode $(\triangle)$

Department of Environment and Natural Science, Kabale

University, Kabale, Uganda

e-mail: odebode04@yahoo.co.uk

J. Stajich

Department of Microbiology and Plant Pathology, University of California, Riverside, USA
( $0.22 \%)$, Aspergillus oryzae $(0.22 \%)$, and Paecilomyces sp. $(0.61 \%)$ and the Mucoromycotina Zygomycetes: Rhizopus oryzae (4.10\%) and Mucor sp. (3.44\%). Fungal concentrations were significantly higher $(P \leq 0.05)$ during the rainy season compared with the dry season. Aspergillus and Penicillium were the most predominant airborne fungal genera while Mucor, Alternaria, and Cladosporium were some of the least observed. Generally, abundance of fungi was significantly high during the wet season in all the studied locations.

Keywords Fungi $\cdot$ Airborne $\cdot$ Lagos

\section{Introduction}

Airborne spore dispersal is an important reproductive dispersal mechanism for many genera of fungi. The small size and hydrophobicity of spores enable long-distance delivery of fungi and can have a great influence on human health and also on plant health. A large fraction of airborne spores originate from agricultural and outdoor environment (Odebode 2017) and the distance they travel depends on so many factors. Microorganisms are abundant in the atmosphere, but their distribution and abundance vary with prevailing environmental situation and also with locations. Usually, a greater concentration is found in urban areas than in the rural areas (Abdel Hameed et al. 2009). The density of airborne microorganisms displays topological, location effect, and seasonal differences 
(Ianovici 2008). As such, airborne microorganism abundance varies with time, year, and location (Bowers et al. 2013). Changes in humidity can also affect the abundance of fungal spores. The distribution of air microbes varies throughout the period in a day depending on weather parameters and has been shown to be influenced by environmental factors including type of vegetation around (Pepeljnjak and Šegvić 2003), air pollution (Lin and Li 2000a, 2000b), human activities going on (Mitakakis et al. 2001), meteorological parameters, and also seasonal variations (Rossi et al. 2005; Klaric and Pepeljnjak 2006). Airborne microorganisms have also been associated with spoilage of food (Tournas and Katsoudas 2005) and damage of books stored in libraries and also materials stored in archives (Aira et al. 2007). They have also been implicated in spread of plant and animal diseases (Rossi et al. 2005). Air distribution of bacteria and fungi poses significant health problems (Balasubramanian et al. 2011). Contact with airborne microorganisms has been linked with allergic respiratory symptoms, asthma exacerbation, asthma-related death, and infection (Dales et al. 2004a, b; Peternel et al. 2004). In Nigeria, little attention has been given to the study of airborne microorganisms. This study therefore investigates the composition and distribution of airborne fungi sampled across multiple locations for 2 years in Lagos State, Nigeria.

\section{Materials and methods}

Five different local governments (county) spread across various parts of Lagos State, Nigeria, were selected for the study (Fig. 1). Except for Victoria Island and Oshodi, all the locations where sampling was done had some form of vegetation like few shrubs at a distance from the sampling location. The locations were chosen to examine a variety of human activities which include an outdoor market, a hospital, a residential area, a high school, and a commercial area.

Atmospheric fungi collection

Airborne fungal spores were sampled monthly for the period of 24 months between May 2014 and
April 2016 at five locations in Lagos, Nigeria (Table 1). The open plate method was used for sampling by opening sterile plates containing dichloran-glycerol 18 (DG-18) agar and potato dextrose agar (PDA). Plates were opened for $10 \mathrm{~min}$ at human height $(1 \mathrm{~m}$ above feet level which is approximately the human breathing zone) and then recovered. Samples were collected in triplicates and transferred to the Mycology Laboratory of the Department of Botany, University of Lagos, and incubated at room temperature (28$31{ }^{\circ} \mathrm{C}$ ) for 3 to 5 days. Colony count and growth appearance were monitored.

The same location was sampled monthly for the entire study period and was always visited at first week of every month.

Identification of fungi

After detection of fungal growth on plates, the topography, texture, and pigmentation of each specific type of colony are noted in order to identify the fungi accurately. The identities of these fungi were identified using cultural and morphological characteristics and by also comparing them with confirmed representatives of different species in relevant texts such as Alexoupolous et al. (2007), Barnett and Hunter (1999), and Ellis (1971).

The percent frequency at which each fungus was observed was calculated as the number of the observations divided by the total number of colonies of fungi from all the sites, throughout the study months.

Molecular methods were also employed to support identification of the sampled fungi to overcome limitations of morphological identification using specific primers (Table 2).

\section{DNA extraction}

For DNA isolation, the cultures were grown in potato dextrose agar (PDA) for 7 days at $28 \pm 1{ }^{\circ} \mathrm{C}$.

Extraction of fungal DNA was done using modified cetyltrimethylammonium bromide (CTAB) protocol (Lee et al. 1998).

DNA extraction and polymerase chain reaction (PCR) were employed to amplify copies of the partial internal transcribed spacer (ITS) fragment of rDNA in vitro. The quality of the PCR product 


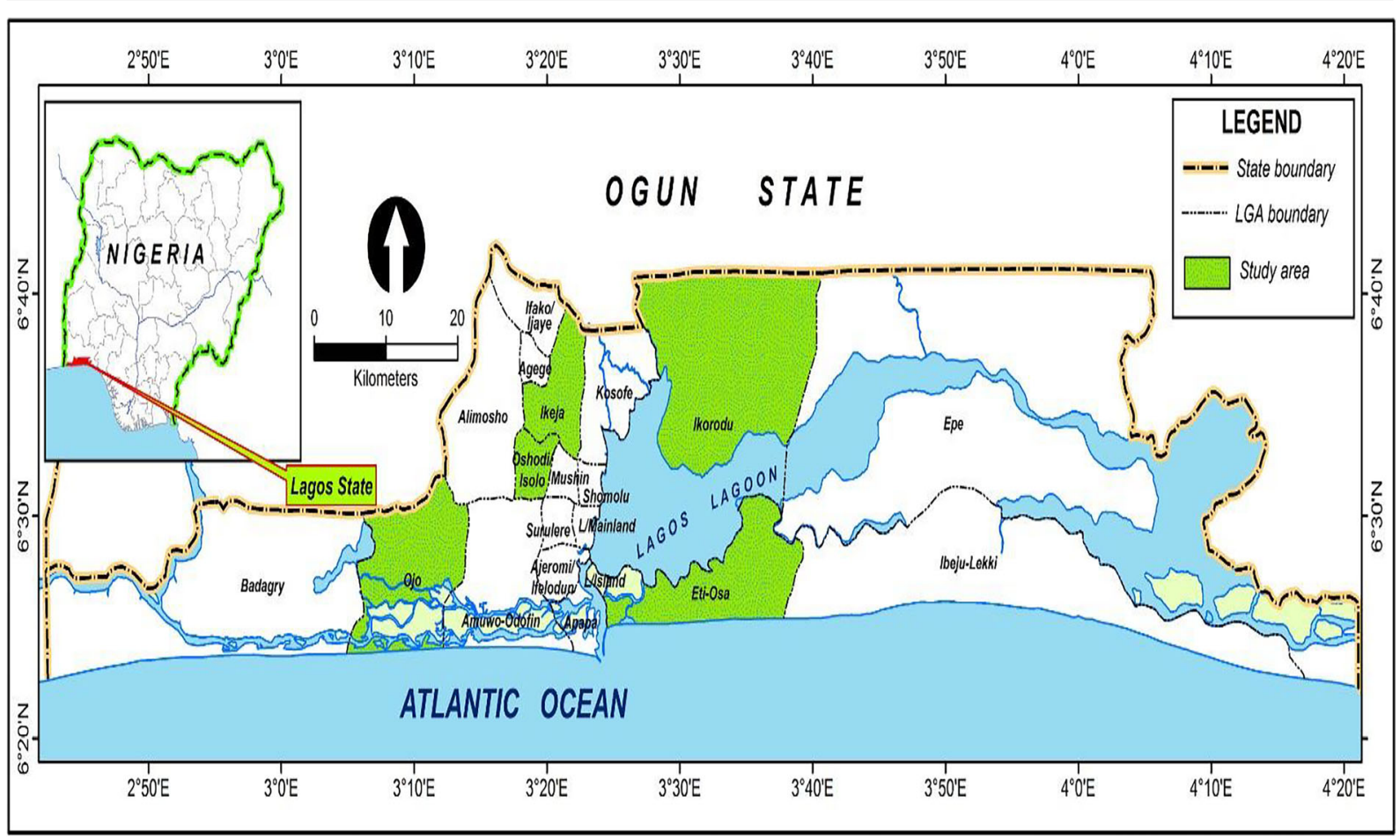

Fig. 1 Map showing sampling locations of air spores from different locations in Lagos State, Nigeria

was assessed by undertaking gel electrophoresis. PCR purification step was carried out to remove unutilized dNTPs, primers, polymerase, and other PCR compounds in order to obtain a highly purified DNA template for sequencing. This procedure also allowed concentration of low-yield amplicons.

PCR amplification program

$94{ }^{\circ} \mathrm{C}$ for $5 \mathrm{~min}, 40$ cycles of $94{ }^{\circ} \mathrm{C}$ for $45 \mathrm{~s}$, $48{ }^{\circ} \mathrm{C}$ for ITS $1\left(52{ }^{\circ} \mathrm{C}\right.$ for TEF and ACT) for $30 \mathrm{~s}, 72{ }^{\circ} \mathrm{C}$ for $90 \mathrm{~s}$ and a final step at $72{ }^{\circ} \mathrm{C}$ for 6 min. All amplicons were sequenced as described by Carbone and Kohn (1999).
Quantification of isolates

Spectrophotometry was used to quantify the DNA obtained and purity was also determined from the A260/ A280 ratio averaged (>1.77).

The amplified PCR products were electrophoresed on a $1 \%$ agarose gel in TBE buffer visualized by staining with ethidium bromide and photographed using a gel documentation system.

Gel extraction and sequencing

Gel extraction and Sanger sequencing of amplicon products were performed using ABI 3730 (Institute for

Table 1 Coordinate descriptions of different sampling locations

\begin{tabular}{llr}
\hline Location & Description & GPS \\
\hline Iba & A farm settlement where fruits and vegetables are grown. & N6027'38, E3012'20 \\
Oshodi & A densely populated area which serves as motor park, garage, and filing & N6033'18, E3020'75 \\
& $\quad$ station with few buildings around. & N6038'51, E3025'25 \\
Ikorodu & A cosmopolitan area with diverse activities including trading, motor park, & N6060'18, E3035'15 \\
Ikeja & A housing, and bus stop. & N6042'81, E3042'19 \\
Victoria Island open recreational space with nearby residential buildings. & \\
\hline
\end{tabular}


Table 2 Primers used for fungi amplification

\begin{tabular}{|c|c|c|c|c|}
\hline Locus & Primer name & Direction & Sequence & Target region \\
\hline Internal transcribed spacer (ITS) & $\begin{array}{l}\text { ITS } 1 \\
\text { ITS } 4\end{array}$ & $\begin{array}{l}\text { Forward } \\
\text { Reverse }\end{array}$ & $\begin{array}{l}\text { 5'TCCGTAGGTGAACCTGCGG3' } \\
\text { 5'TCCTCCGCTTATTGATATGC3' }\end{array}$ & 18S rDNA \\
\hline Large ribosomal unit & $\begin{array}{l}\text { LRO5 } \\
\text { LROR }\end{array}$ & $\begin{array}{l}\text { Forward } \\
\text { Reverse }\end{array}$ & $\begin{array}{l}\text { 5'TCCTGAGGGAAACTTCG3' } \\
\text { 5'ACCCGCTGAACTTAAGC 3' }\end{array}$ & LSU \\
\hline
\end{tabular}

Integrative Genomes Biology, Genomics Core facility, University of California, Riverside). After sequencing, the sequences obtained were blasted using Basic Local Alignment Search Tool (BLAST) to identify the closest affiliated sequences in NCBI database.

Statistical analysis

Fungal spores data obtained were analyzed using multiple analysis of variance (ANOVA) and means were separated using Duncan multiple range test (DMRT) with the level of significance at $P<0.05$ (95\% confidence interval). Histograms and line graphs were also used for graphical representations.

Rainfall data was obtained from Nigerian Meteorological Agency, Oshodi, Lagos, Nigeria.

\section{Results}

Below are the results of the 23S rRNA data of the sequenced fungi (Table 3 ).

Means with different superscripts are significantly different. Mean separation was done with the Duncan multiple range test at $P<0.05$. Abundance of fungal spores in different locations with respect to media showed that for the different locations in Lagos State, Iba produced significant difference $(P<0.05)$ from other locations for both PDA and DG-18 agar followed by Ikeja (20.83 and 24.00) while Ikorodu had the lowest value (19.38) with respect to both media (Fig. 2). In all the locations, DG-18 media produced significant difference than PDA (Table 4).

The second year of collection had higher monthly percentage fungi spores collected than the first year. There was gradual increase in fungal spore collection from the months of March, April, and May, and highest collection was in June. Higher values were observed during the periods of May-August which are significantly different $(P \leq 0.05)$ from the values observed early and later part of the year (Table 4 ).

Thirty-six different fungal spore types were collected from Iba. The atmosphere was dominated by fungal spores from majorly Ascomycetes and Deuteromycetes. Aspergillus flavus was the most frequently collected followed by Aspergillus niger and Penicillium funiculosum. The fewest spores were recorded from Phoma eupyrema, Aspergillus subramanianii, and Aphaderanum sp. Other fungal species include Penicillium funiculosum, Aspergillus protuberus, Fusarium verticillioides, Neurospora crassa, and Penicillium citrinum (Fig. 3).

Thirty-four fungal spores belonging to different species were isolated from Ikorodu location. The atmosphere was dominated with varied fungal species of different fungal spores especially those of Ascomycetes and Deuteromycetes including Aspergillus niger, A. flavus, and A. fumigatus. Lowest record of fungal spores was observed for Aphaderanum sp., Trichoderma viride, and Penicillium pinophilum (Fig. 4).

Twenty-eight fungal spores were recorded from the aeroflora for the duration of sampling belonging to different families for Ikeja location. Dominant spores were A. niger, A. sydowii, and A. flavus. Others which were sporadic include those of Aphaderanum sp., Curvularia sp., and A. oryzae. Other fungi spores isolated also include Paecilomyces sp., Mucor sp., Neurospora crassa, P. funiculosum, P. simplicissimum, $P$. oxalicum, P. pinophilum, F. verticillioides, and Rhizopus oryzae (Fig. 5).

Twenty fungal spores were identified from aeroflora of Victoria Island, Lagos, Nigeria. Dominant fungi include those of Aspergillus niger, A. fumigatus, and Penicillium notatum, while spores of Rhizopus sp., T. helicum, and A. oryzae recorded the lowest abundance of spores. Other spore types were identified, among which include A. aculeatinus, $P$. pinophilum, $P$. citrinum, Fusarium sublunatum, Trichoderma viride, and Mucor sp. (Fig. 6). 
Table 3 Molecular identification of fungi isolated from different sampling sites

\begin{tabular}{|c|c|c|c|c|}
\hline Sample & Organism & Match identity (\%) & $E$ value & Query cover \\
\hline 31 ITS & Aspergillus aculeatinus & 99 & $1 \mathrm{e}$ & 285 \\
\hline 1 ITS & A. flavus & 94 & $3 e$ & 345 \\
\hline 25 ITS & A. fumigatus & 97 & $3 \mathrm{e}$ & 305 \\
\hline $24 \mathrm{LR}$ & A. niger & 99 & $1 \mathrm{e}$ & 138 \\
\hline $34 \mathrm{LR}$ & A. niger & 95 & $2 \mathrm{e}$ & 301 \\
\hline $6 \mathrm{LR}$ & A. ochraceus & 98 & $3 e$ & 175 \\
\hline 9 ITS & A. oryzae & 99 & $2 \mathrm{e}$ & 302 \\
\hline 41 ITS & A. oryzae & 96 & $2 \mathrm{e}$ & 233 \\
\hline 30 ITS & A. penicilloides & 96 & $3 e$ & 175 \\
\hline $14 \mathrm{LR}$ & A. protuberus & 97 & $4 \mathrm{e}$ & 309 \\
\hline $4 \mathrm{LR}$ & A. subramanianii & 99 & $3 \mathrm{e}$ & 169 \\
\hline 29 ITS & A. tamari & 96 & $3 \mathrm{e}$ & 238 \\
\hline $5 \mathrm{LR}$ & A. tubingensis & 93 & $4 \mathrm{e}$ & 254 \\
\hline 36 ITS & Absidia blakesiana & 96 & $1 \mathrm{e}$ & 197 \\
\hline 39 ITS & Aphaderanum spp. & 97 & $2 \mathrm{e}$ & 192 \\
\hline 7LR & Aspergillus terreus & 95 & $2 \mathrm{e}$ & 256 \\
\hline 19 ITS & Cladosporium herbarium & 97 & $3 e$ & 201 \\
\hline 14 ITS & Curvularia spp. & 95 & $2 \mathrm{e}$ & 145 \\
\hline 10 ITS & F. verticillioides & 99 & $4 \mathrm{e}$ & 269 \\
\hline $17 \mathrm{LR}$ & Fusarium sublunatum & 99 & $4 \mathrm{e}$ & 239 \\
\hline 13 ITS & Mucor spp. & 96 & $3 \mathrm{e}$ & 166 \\
\hline 35 ITS & Neurospora crassa & 97 & $4 \mathrm{e}$ & 234 \\
\hline 40 ITS & P. chrysogenum & 98 & $3 e$ & 256 \\
\hline $16 \mathrm{LR}$ & P. citrinum & 86 & $3 \mathrm{e}$ & 345 \\
\hline 20LR & P. citrinum & 97 & $1 \mathrm{e}$ & 198 \\
\hline 25LR & P. oxalicum & 99 & $3 e$ & 209 \\
\hline 26LR & P. pinophilum & 96 & 1e & 354 \\
\hline $27 \mathrm{LR}$ & P. simplicissimum & 98 & $2 \mathrm{e}$ & 233 \\
\hline 33LR & Paecilomyces spp. & 99 & $1 \mathrm{e}$ & 276 \\
\hline $11 \mathrm{LR}$ & Penicillium funiculosum & 100 & $2 \mathrm{e}$ & 147 \\
\hline 23LR & Perenniporia koreana & 97 & $2 \mathrm{e}$ & 324 \\
\hline 33 ITS & Phoma eupyrema & 98 & $1 \mathrm{e}$ & 304 \\
\hline 12 ITS & Rhizopus stolonifer & 97 & $2 \mathrm{e}$ & 197 \\
\hline 21 ITS & Sistotrema brinkmanii & 95 & $1 \mathrm{e}$ & 179 \\
\hline 19LR & T. asperellum & 97 & $3 \mathrm{e}$ & 198 \\
\hline $8 \mathrm{LR}$ & T. harzianum & 87 & $2 \mathrm{e}$ & 321 \\
\hline 7 ITS & T. helicum & 97 & $2 \mathrm{e}$ & 230 \\
\hline $32 \mathrm{LR}$ & T. viride & 99 & $3 \mathrm{e}$ & 124 \\
\hline 18LR & Trichoderma harzanium & 98 & $3 e$ & 234 \\
\hline
\end{tabular}

Twenty-seven different fungal spores were isolated from Oshodi location. Ascomycetes and Deuteromycetes spores were the major contributors. Penicillium notatum, A. niger, and A. fumigatus were the most occurring fungal spores while $P$. simplicissimum, Aphaderanum sp., and Phoma eupyrema were the lowest in abundance (Fig. 7). The frequency chart also showed that Iba had the highest fungal spore collection during the 2-year survey (Fig. 8). 
Fig. 2 Abundance of fungal spores in different locations in Lagos State

\section{MEDIA}

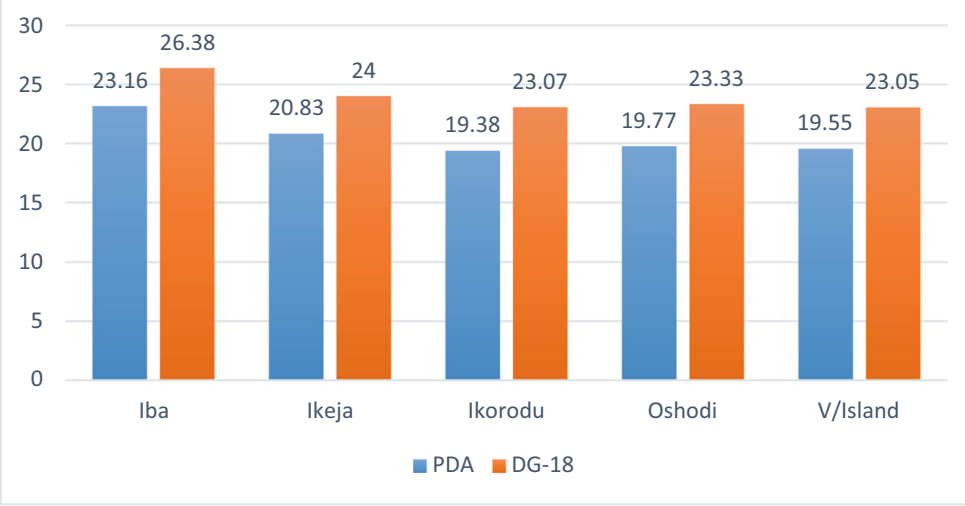

For rainfall, the $r$ value was $0.20, P$ value was 0.33 while slope was 5.72 (Fig. 9). Relative humidity had slope of 3.74, $P$ value of 0.01 , and $r$ value of 0.62 (Fig.

Table 4 Monthly comparison of abundance of fungal spores isolated

\begin{tabular}{|c|c|c|c|}
\hline Year & Months & PDA & DG-18 \\
\hline \multirow[t]{8}{*}{2014} & May & $23.40 \mathrm{~cd}$ & $27.20 \mathrm{bc}$ \\
\hline & June & $25.20 \mathrm{ab}$ & $29.20 \mathrm{~b}$ \\
\hline & July & $23.40 \mathrm{~cd}$ & $26.40 \mathrm{cde}$ \\
\hline & August & $21.20 \mathrm{fg}$ & $24.40 \mathrm{ef}$ \\
\hline & September & $21.20 \mathrm{fg}$ & $24.80 \mathrm{def}$ \\
\hline & October & $21.60 \mathrm{efg}$ & $24.20 \mathrm{f}$ \\
\hline & November & $17.20 \mathrm{~h}$ & $20.00 \mathrm{ghi}$ \\
\hline & December & $14.80 \mathrm{i}$ & $18.40 \mathrm{i}$ \\
\hline \multirow[t]{12}{*}{2015} & January & $17.40 \mathrm{~h}$ & $21.20 \mathrm{~g}$ \\
\hline & February & $17.20 \mathrm{~h}$ & $20.80 \mathrm{~g}$ \\
\hline & March & $20.00 \mathrm{~g}$ & $23.80 \mathrm{f}$ \\
\hline & April & $21.40 \mathrm{fg}$ & $24.40 \mathrm{ef}$ \\
\hline & May & $23.20 \mathrm{cde}$ & $26.80 \mathrm{~cd}$ \\
\hline & June & $26.00 \mathrm{a}$ & $31.40 \mathrm{a}$ \\
\hline & July & $24.00 \mathrm{bc}$ & $27.20 b c$ \\
\hline & August & $21.80 \mathrm{def}$ & $25.00 \mathrm{def}$ \\
\hline & September & $22.00 \mathrm{def}$ & $25.60 \mathrm{cdef}$ \\
\hline & October & $22.00 \mathrm{def}$ & $24.60 \mathrm{ef}$ \\
\hline & November & $17.40 \mathrm{~h}$ & 20.20ghi \\
\hline & December & $15.20 \mathrm{i}$ & 18.60hi \\
\hline \multirow[t]{6}{*}{2016} & January & $17.40 \mathrm{~h}$ & $21.60 \mathrm{~g}$ \\
\hline & February & $17.20 \mathrm{~h}$ & $20.60 \mathrm{gh}$ \\
\hline & March & $20.60 \mathrm{fg}$ & $24.00 \mathrm{f}$ \\
\hline & April & $21.80 \mathrm{def}$ & $23.80 \mathrm{f}$ \\
\hline & LSD & 1.65 & 2.05 \\
\hline & EMS & 1.74 & 2.66 \\
\hline
\end{tabular}

10). Temperature had slope of $-0.58, r$ value of -0.31 , and $P$ value of 0.004 (Fig. 11). For wind, slope was $0.82, P$ value was 0.074 , and $r$ value was 0.37 (Fig. 12).

The meteorological data covering the months of May 2014 to April 2016 for Lagos also showed a fairly steady weather parameter for 2 years (Fig. 13).

\section{Discussion}

The occurrence of airborne spores in outdoor environments as well as their abundance, their diversity, and their impact on human, animal, and plant health is gaining attention globally. This study provides information on the relative abundance of fungi from five different locations in Lagos State, Nigeria. The similarities in the distribution and abundance of fungi spores can be influenced by vegetation and close meteorological data (Abdel Hameed et al. 2009). A previous work has examined the composition and dispersal of airborne fungi spores in indoor and outdoor environments in developed countries, but few studies have been carried out in Nigeria. To the best of our knowledge, this is the first study of fungal diversity in the Lagos atmospheric environment, combining identification by direct microscopy with molecular analysis. The combination of the two methodologies allowed us to identify 39 genera and species from airborne spores that make up the environmental mycobiota of Lagos, Nigeria. In this study, fungi isolated included A. flavus, Penicillium spp., Fusarium spp., and Alternaria spp. which have also been previously found to be abundant airborne species. Penicillium spp. and Aspergillus spp. were the most frequent fungi that we observed in the cultures. Differences in 


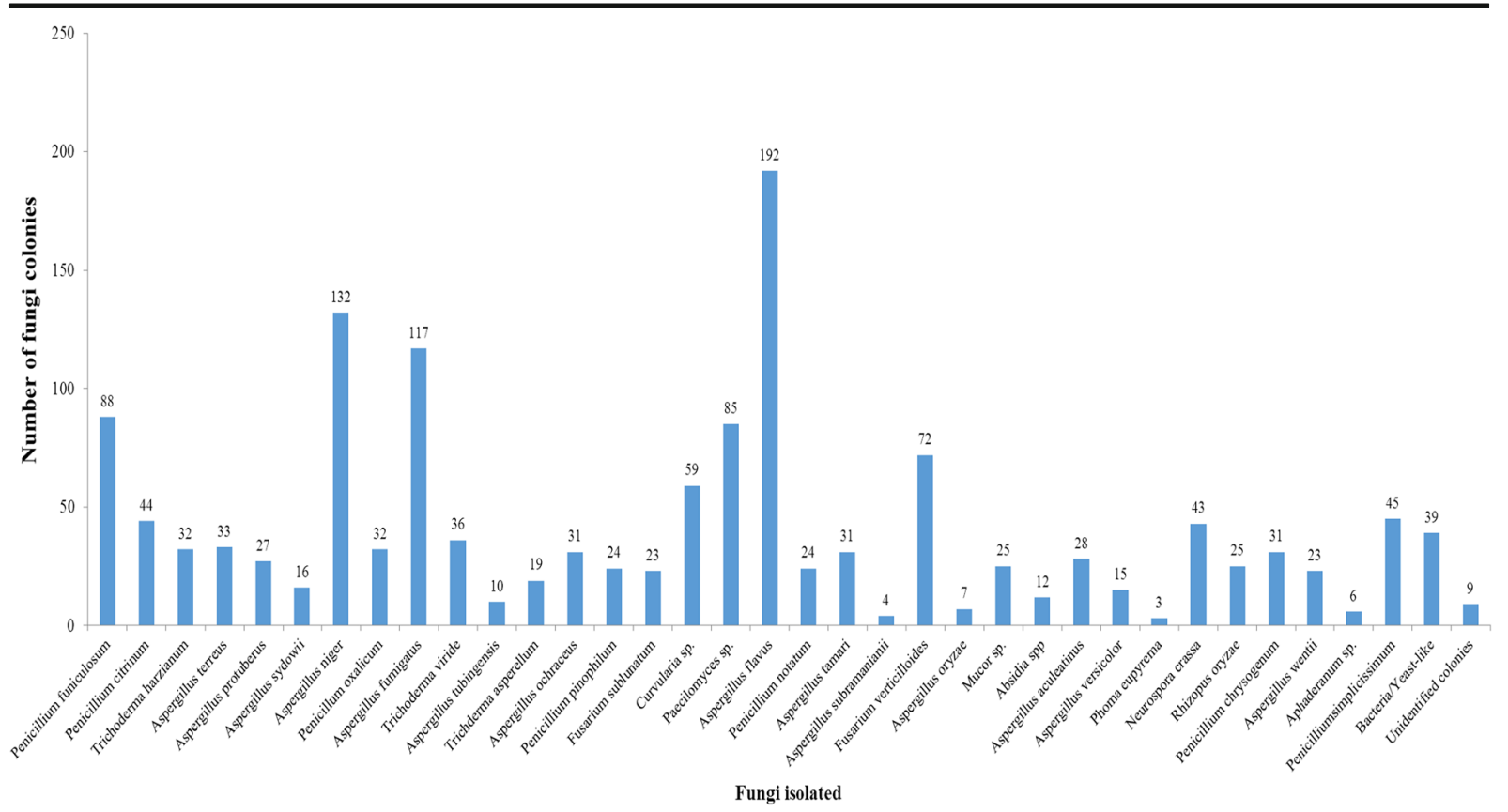

Fig. 3 Abundance of fungi isolated in Iba, Lagos state

recovery of fungi on the two media types found that more colonies were typically found on DG-18 agar than PDA in all sampled locations.

There was also significant variation in the abundance of fungi across different times of the year. Fungi were quantitatively high during the rainy (May-October) season and comparatively lesser in the dry (NovemberMarch) season, consistent with other observations of fungal abundance periodicity (Rangaswamy et al. 2013). The variations in the airborne fungi at various

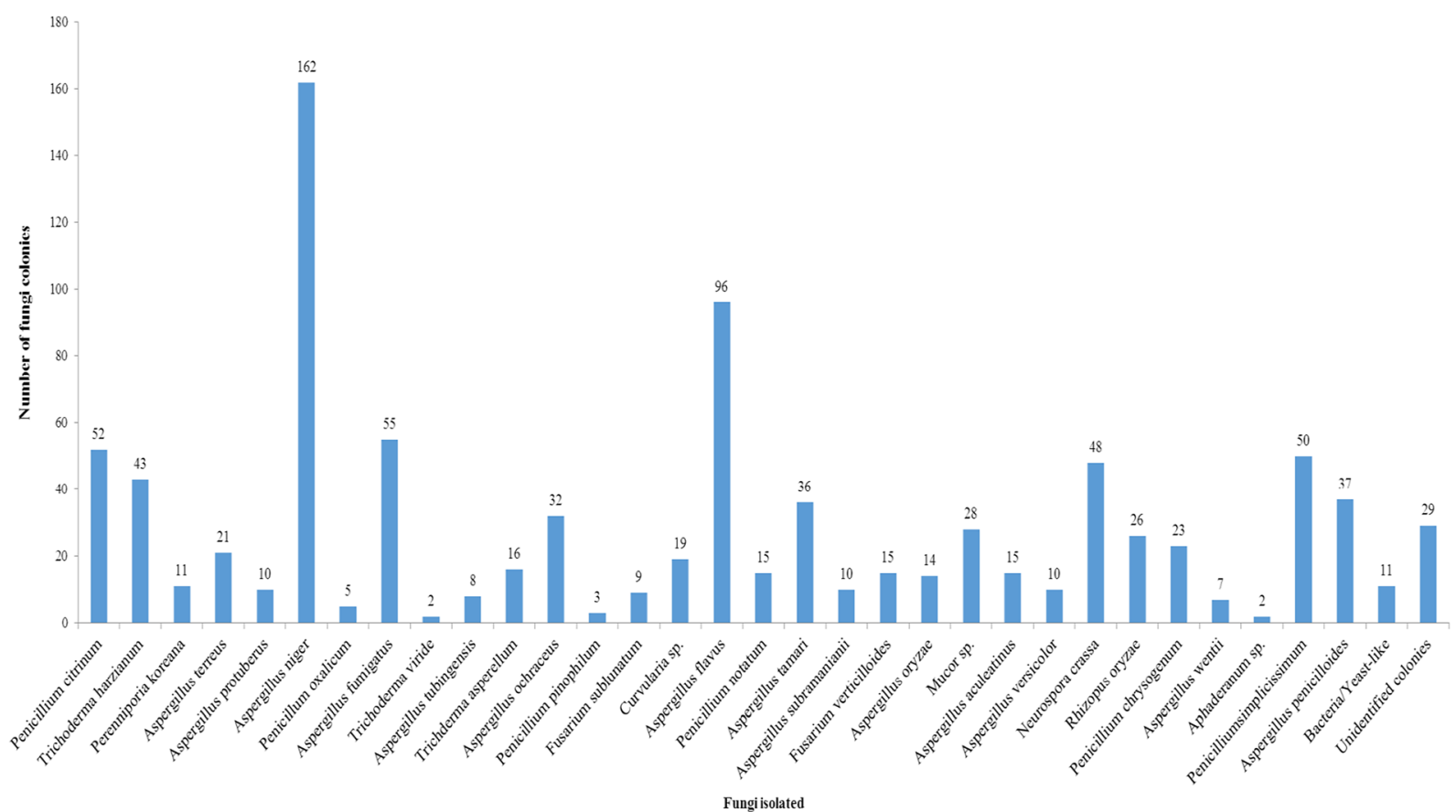

Fig. 4 Abundance of fungi isolated in Ikorodu, Lagos State 


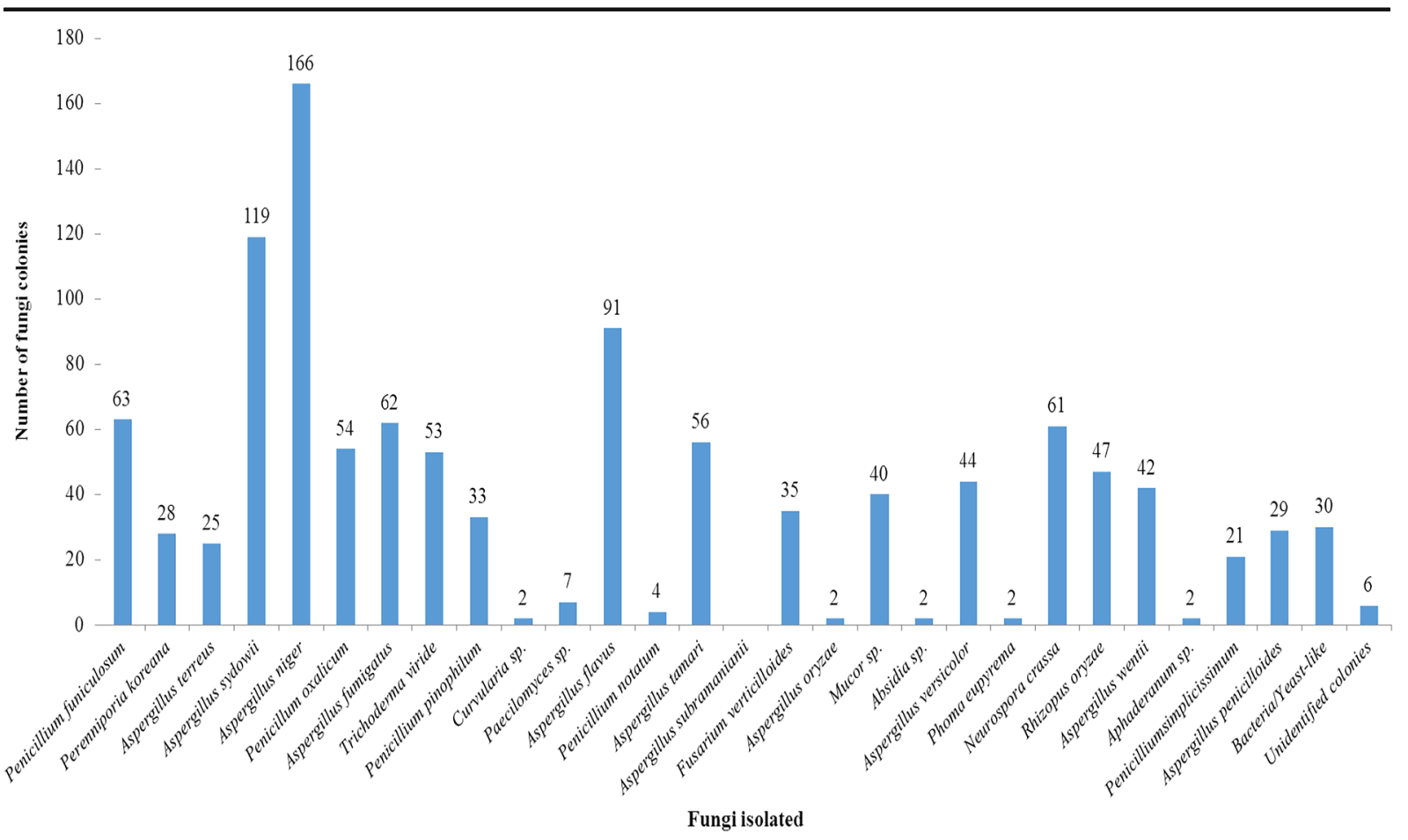

Fig. 5 Abundance of fungi isolated in Ikeja, Lagos State

locations can be said to be as a result of a variety of source environments which include the soils, leaf surfaces, and lush green grasses and various activities going on in the environment. The activities which go on around the environment also play a crucial role in the abundance of these organisms in the atmosphere

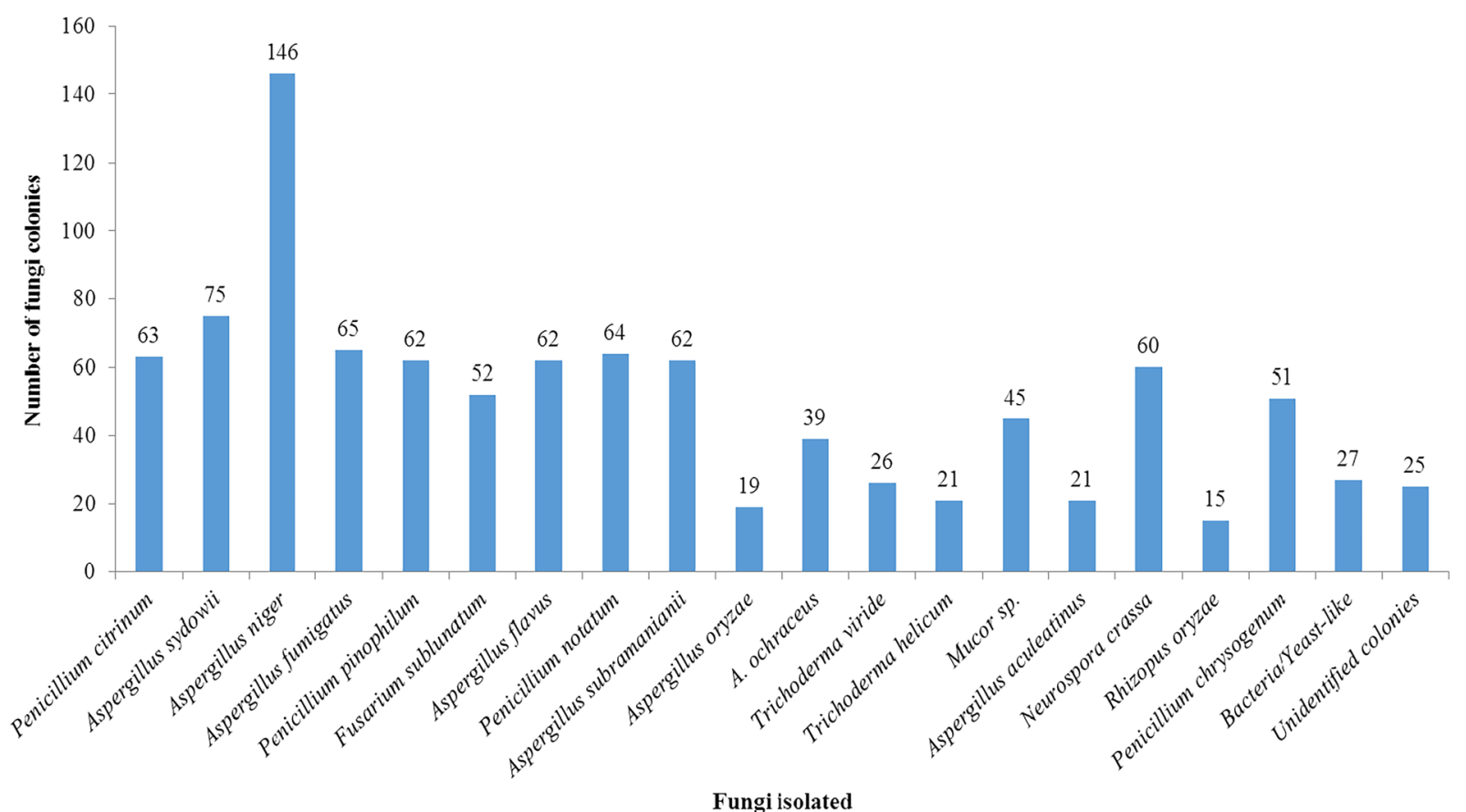

Fig. 6 Abundance of fungi isolated in Victoria Island, Lagos State 


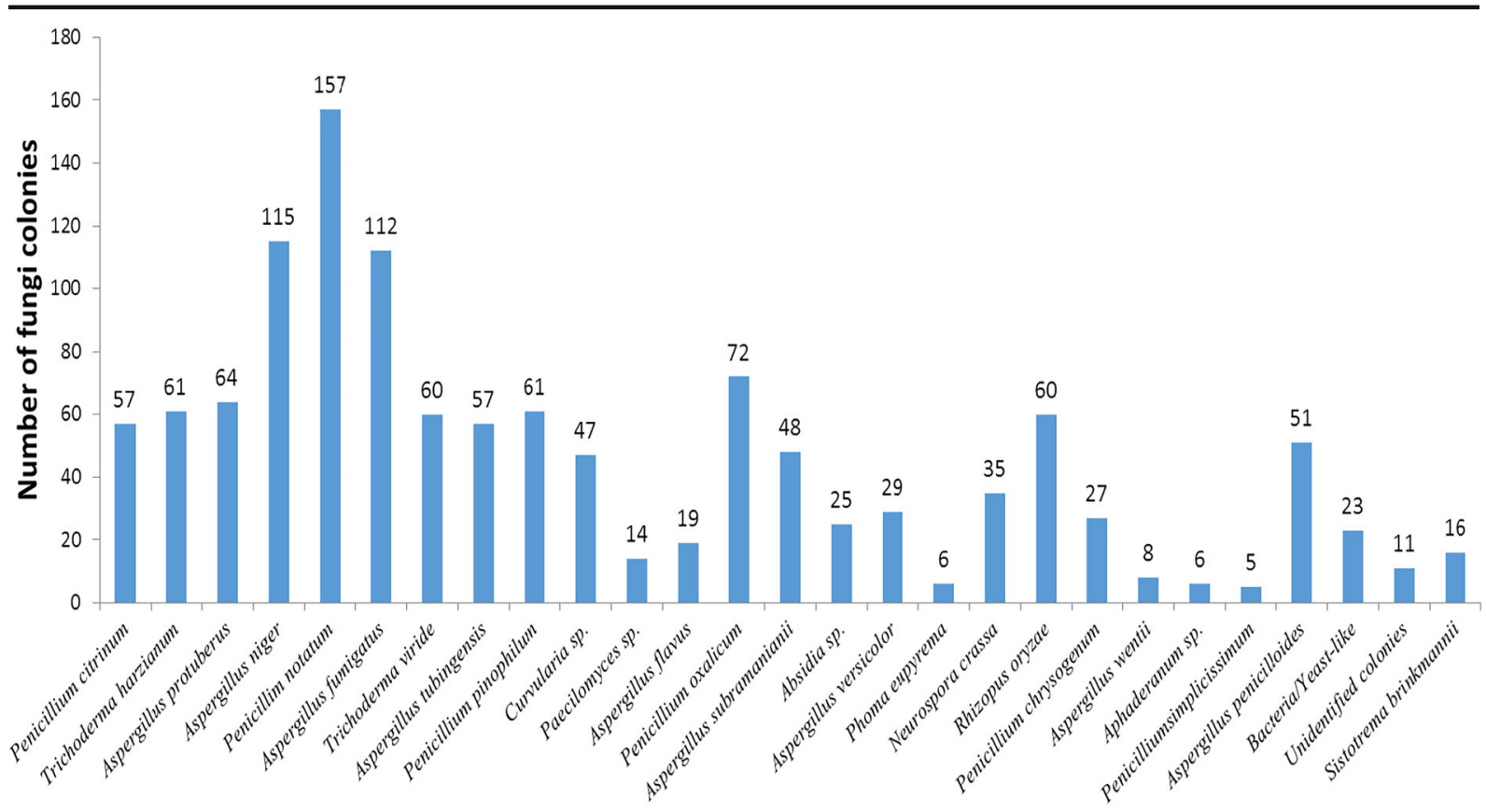

Fungi isolated

Fig. 7 Abundance of fungi isolated in Oshodi, Lagos State

because it was found out that locations where there was high vehicular and human traffic had more fungal spores in the atmosphere compared with locations like Victoria Island which had low human activities going on in the area. Iba, Ikorodu, and Ikeja recorded the higher number of fungi was likely due to the human activities occurring at these places because they were outdoor market, hospital, and farm settlement areas where hustling and

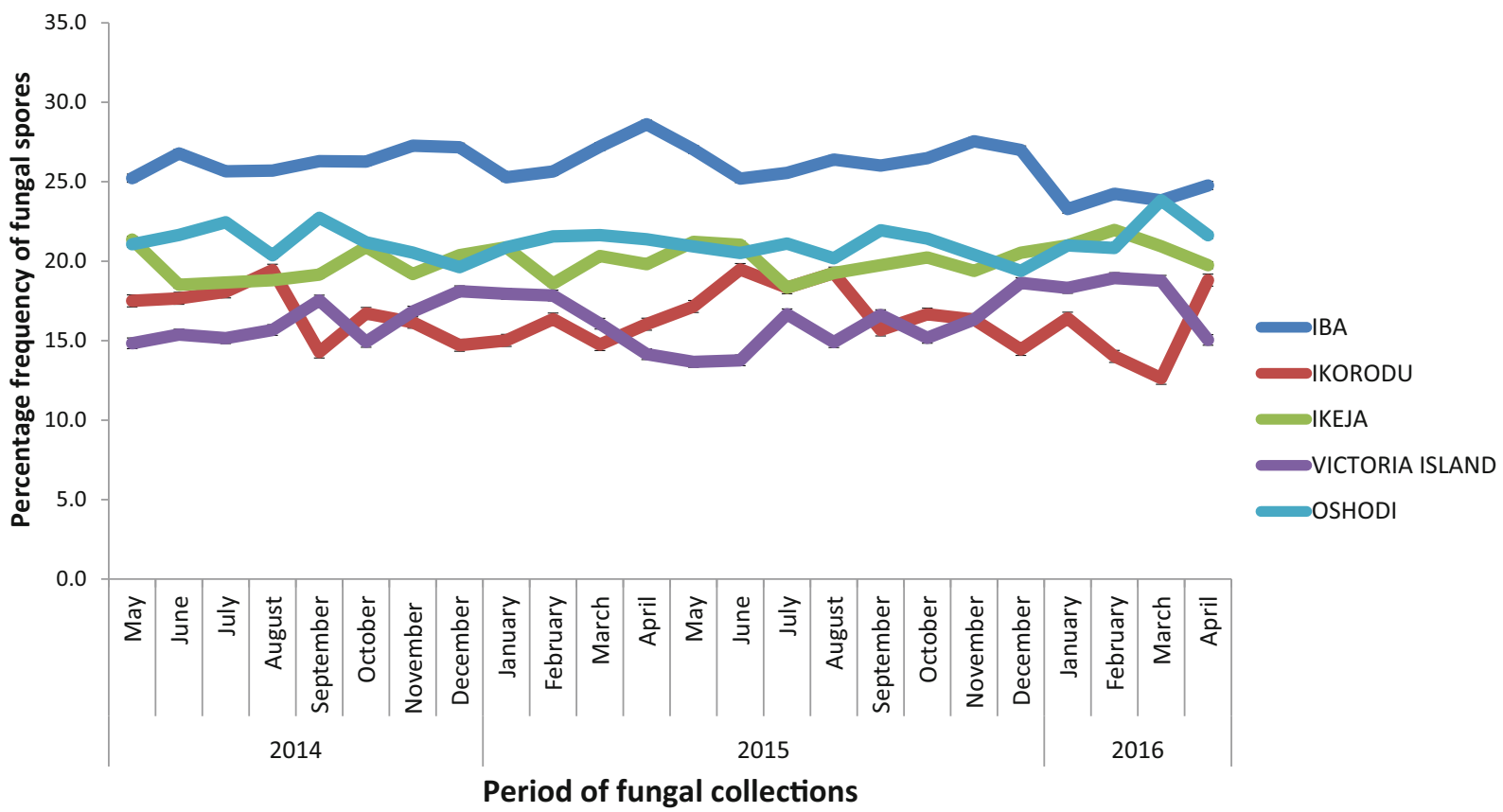

Fig. 8 Frequency of fungi occurrence in Lagos, State 


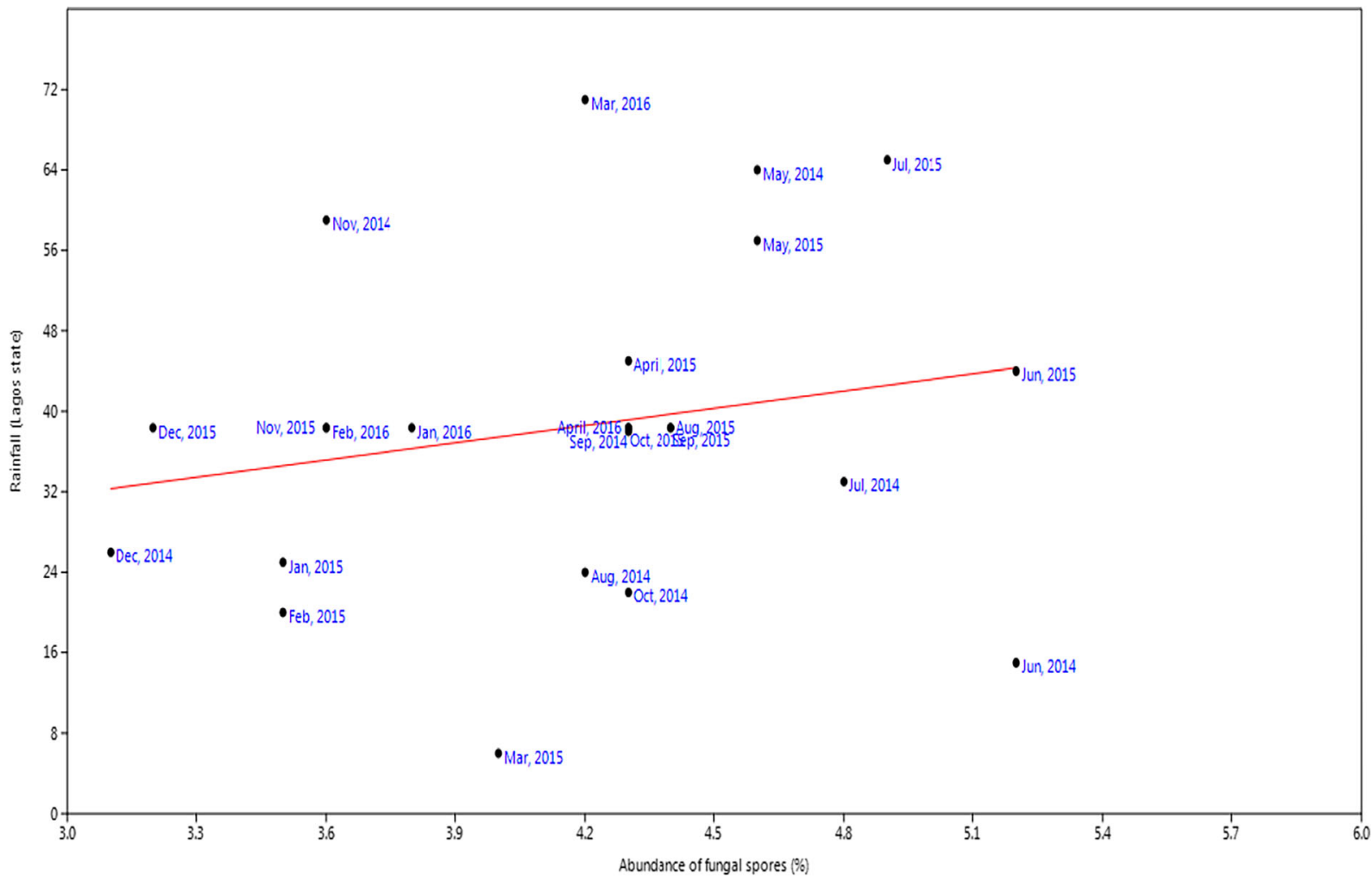

Fig. 9 Multivariate linear regression between fungal spore abundance and rainfall in Lagos

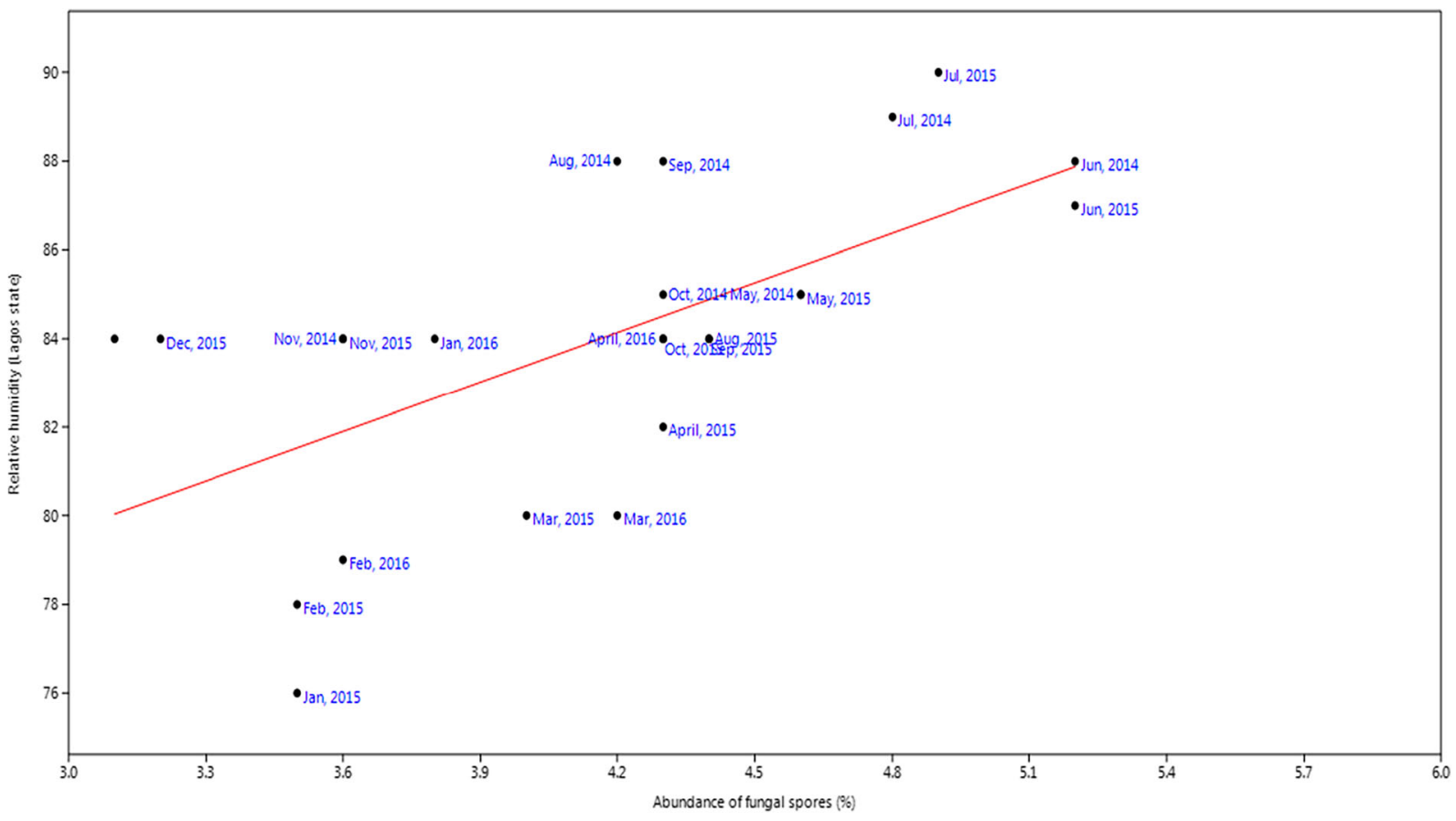

Fig. 10 Multivariate linear regression between fungal spore abundance and relative humidity in Lagos 


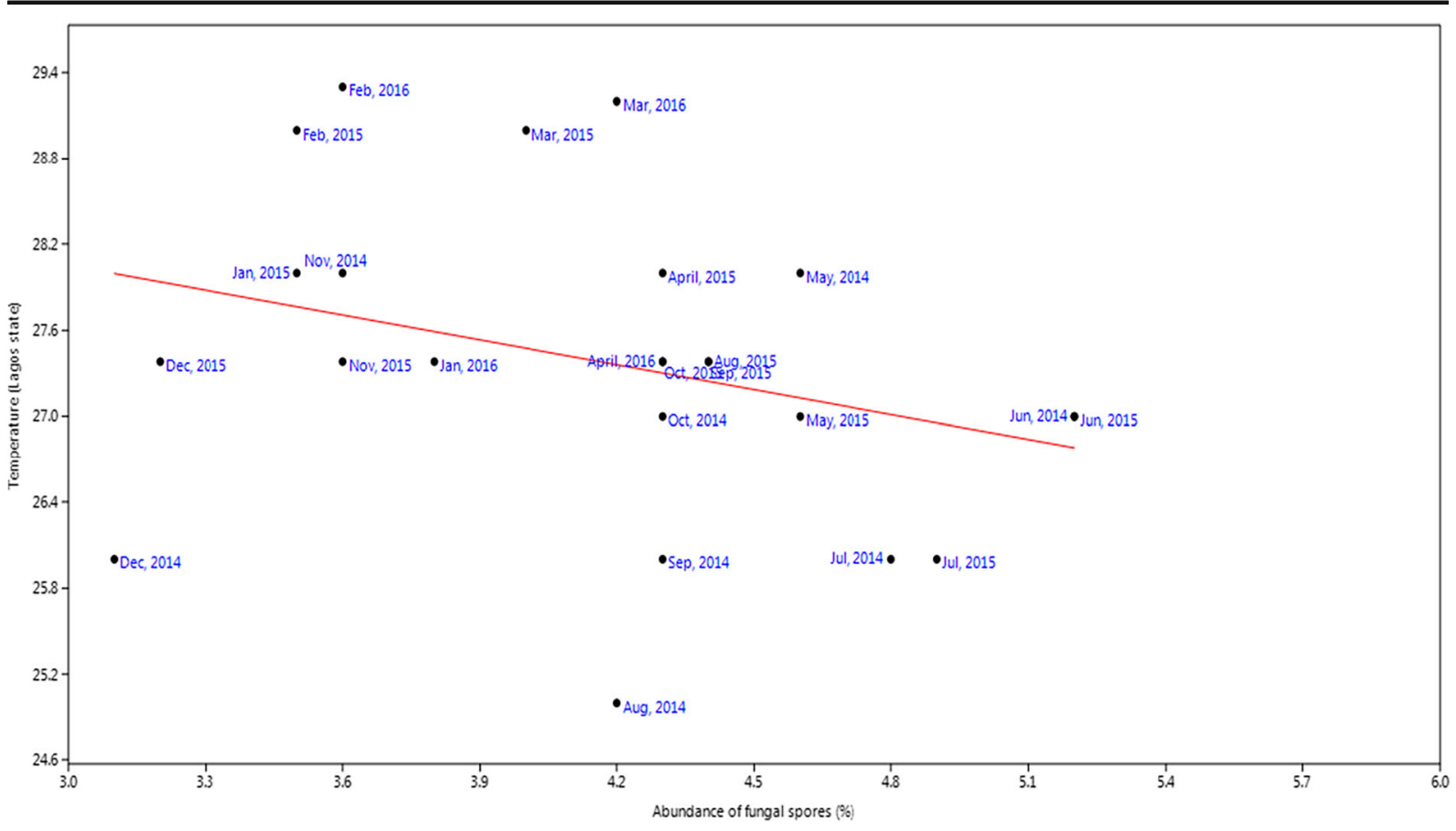

Fig. 11 Multivariate linear regression between fungal spore abundance and temperature in Lagos

bustling do occur on a daily basis and also high wind speed re-suspends these organisms in the atmosphere. Our work is consistent with a previous report that microbial abundance is correlated with population density and activity (Fang et al. 2007). The hospital environment at Ikeja recorded high fungal spore counts which may be a result of foot and vehicle traffic which increases disturbance. Huang et al. (2014) also observed

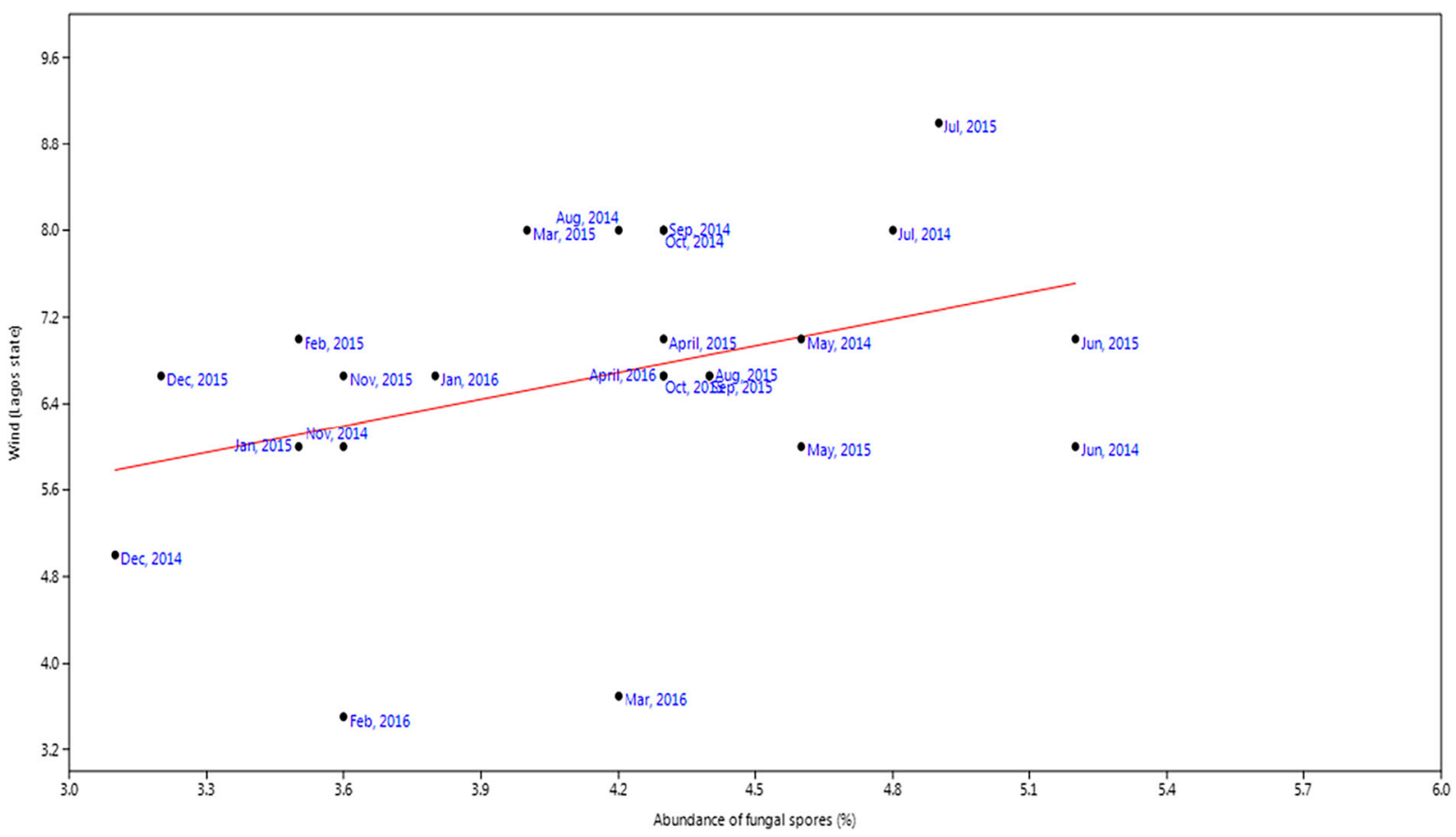

Fig. 12 Multivariate linear regression between fungal spore abundance and wind speed in Lagos 


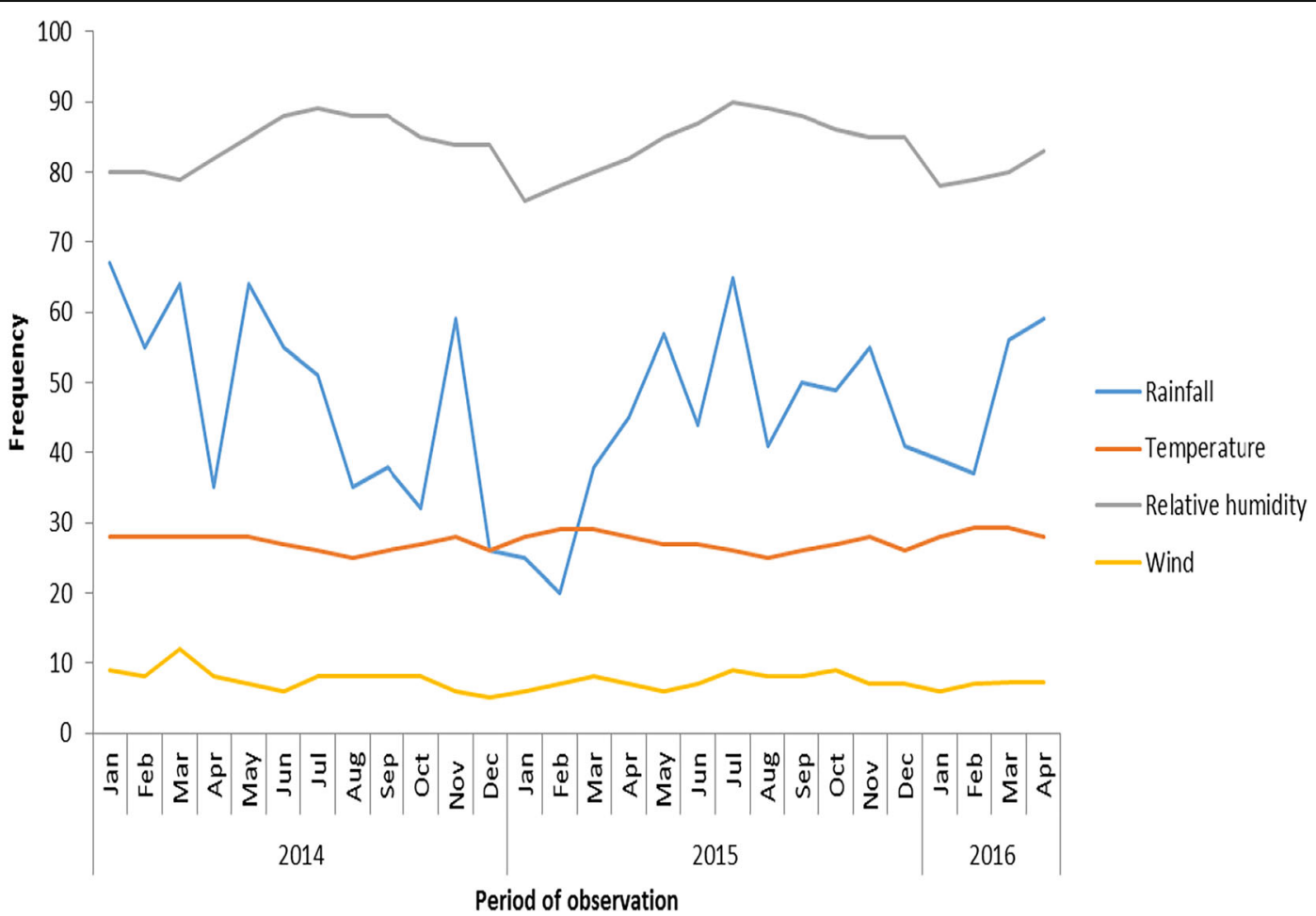

Fig. 13 Meteorological data for Lagos State during the period of fungi collection. Source: Nigerian Meteorological Agency

the same pattern in their work. The reduced number of fungi observed at Victoria Island could be due to prevailing atmospheric conditions since it is an ocean environment and there are few visitors during weekdays.

We found Aspergillus species was the most common genus near the hospital location which is consistent with previous findings of fungi from the air in hospital environment (Ekhaise et al., 2008). We also found that Aspergillus and Penicillium species are the most abundant fungal isolates across the sampled locations. Aerosolized Aspergillus spores are found nearly everywhere so humans are routinely and almost constantly exposed to them. These fungal spores contain allergenic protein and it has been reported that exposure to fungal allergens is a strong risk factor for asthma symptom (Denning et al. 2006). Makut et al. (2014) used plate sedimentation method during their investigation of microflora of outdoor air in Nasarawa State, Nigeria, and found that six bacterial species which belong to 6 genera and nine fungal species which belong to 7 genera were identified at various frequencies of distribution. Tsai and Macher (2005) found A. fumigatus and A. flavus as the major fungal species in their sampling of the US homes and therefore classified them as the most probable cause of allergic effects and may be possibly hazardous to the health of workers. In our study, a total of thirty-nine different fungal species were identified from various locations. From the Aspergillus genus, 12 species were identified of which A. flavus, A. fumigatus, A. niger, and A. terreus were the most common species sampled while for Penicillium, 6 species were identified. Months with high relative humidity and rainfall witnessed significant increase in fungal spore collection throughout the period of sampling. The lowest total number of colonies was obtained in the month of December for both potato dextrose agar and DG-18 agar. The abundance of some of the major fungal spores could be a marker for pathogenicity in the environment and should warn the farmers to protect their crops from diseases. According to Njokuocha (2006), most of the fungi species identified in the air have also been associated with agricultural crop and wild plant diseases in Nsukka, Nigeria. Njokuocha and Ukeje (2006) also proposed that fungal spores are diverse in distribution and represent a large proportion of the airborne spores sampled in most aerobiology studies. Majority of the fungal spores obtained in their work are also among the invasive airborne fungal spores that have been linked with patients with solid organ transplants in hospitals (Sanchez and Bush 2001; Cashel et al. 2004). The internal transcribed 
spacer (ITS) region has the highest probability of successful identification for the broadest range of fungi. The combinations of both ITS and LSU sequences have been applied in environmental sampling (Gorfer et al. 2011).

\section{Conclusion}

These distribution, frequency, and types of fungi found in this sampling can better inform at risk including those suffering from respiratory diseases and allergy in the types and locations of outdoor activities. It was important to note that fungal spores are ubiquitous but abundance does vary with rainfall and location, and future work to examine the factors that better predict the cycles of fungal spore abundance in Nigeria may provide helpful information to the public and public health agencies.

Funding information We would like to appreciate the West African Research Association Fellowship for the travel grant awarded Adeyinka Odebode to conduct a part of the research work in the USA.

Open Access This article is licensed under a Creative Commons Attribution 4.0 International License, which permits use, sharing, adaptation, distribution and reproduction in any medium or format, as long as you give appropriate credit to the original author(s) and the source, provide a link to the Creative Commons licence, and indicate if changes were made. The images or other third party material in this article are included in the article's Creative Commons licence, unless indicated otherwise in a credit line to the material. If material is not included in the article's Creative Commons licence and your intended use is not permitted by statutory regulation or exceeds the permitted use, you will need to obtain permission directly from the copyright holder. To view a copy of this licence, visit http://creativecommons.org/licenses/by/4.0/.

\section{References}

Abdel Hameed, A. A., Khoder, M. I., Yuosra, S., Osman, A. M., \& Ghanem, S. (2009). Diurnal distribution of airborne bacteria and fungi in the atmosphere of Helwan area, Egypt. Sci Total Environ, 407, 6217-6222.

Aira, M., Jato, V., Stchigel, A., Rodríguez-Rajo, F., \& Piontelli, E. (2007). Aeromycological study in the Cathedral of Santiago de Compostela (Spain). International Biodeterioration and Biodegradation, 60, 231-237.

Alexoupolous, C. J., Mims, C. W., \& Blackwell, M. (2007). Introductory mycology (Fourth ed.869pp). New Delhi: Wiley India.

Balasubramanian, R., Nainar, P., \& Rajaseka, A. (2011). Airborne bacteria, fungi, and endotoxin levels in residential microenvironments: a case study. Aerobiologia, 21. https://doi.org/10.1007/s10453-011-9242-.

Barnett, H., \& Hunter, B. (1999). Illustrated genera of imperfect fungi (4th ed.p. 218). St. Paul, MN: TheAmerican Phytopathological Society, APS.

Bowers, R. M., Clements, N., Emerson, J. B., Wiedinmyer, C., Hannigan, M. P., \& Fierer, N. (2013). Seasonal variability in bacterial and fungal diversity of the near-surface atmosphere. Environmental Science \& Technology, 47, 12097-12106. https://doi.org/10.1021/es402970s.

Carbone, I., \& Kohn, L. M. (1999). A method for designing primer sets for speciation studies in filamentous ascomycetes. Mycologia., 91, 553-556.

Cashel, P., Newhouse, B. S., \& Levetin, E. (2004). Correlation of environmental factors with asthma and rhinitis symptoms in Tulsa, Okhlahoma. Annals of Allergy, Asthma and Immunology., 92, 356-366.

Dales, R., Cakmak, S., Judek, S., Dann, T., Coates, F., Brook, J., \& Burnett, R. (2004a). Influence of outdoor aeroallergens on hospitalization for asthma in Canada. The Journal of Allergy and Clinical Immunology, 113, 303-306.

Dales, R. E., Cakmak, S., Judek, S., Dann, T., Coates, F., Brook, J. R., \& Burnett, R. T. (2004b). The role of fungal spores in thunderstorm asthma. Chest., 123, 745-750.

Denning, D. W., O’Driscoll, B. R., Hogaboam, C. M., Bowyer, P., \& Niven, R. M. (2006). The link between fungi and severe asthma: a summary of the evidence. The European Respiratory Journal, 27, 615-626.

Ekhaise, F. O., Ighosewe, O. U. and Ajakpovi, O. D. (2008). Hospital indoor airborne microflora in private and government owned hospitals in Benin City, Nigeria. World Journal of Medical Science. 3(1) 19-23.

Ellis, M. (1971). Dematiaceous hyphomycetes (p. 608). London and Reading Commonwealth Mycological Institute Kew, Surrey, UK: The Western Press Ltd.

Fang, Z., Ouyang, Z., Zheng, H., Wang, X., \& Hu, L. (2007). Culturable airborne bacteria in outdoorenvironments in Beijing, China. Microbial Ecol, 54, 487-496.

Gorfer, M., Blumhoff, M., Klaubauf, S., Urban, A., Inselsbacher, E., Bandian, D., Mitter, B., Sessitsch, A., Wanek, W., \& Strauss, J. (2011). Community profiling and gene expression of fungal assimilatory nitrate reductases in agricultural soil. The ISME Journal, 5, 1771-1783.

Huang, X. H., Bian, Q., Ng, W. M., Louie, P. K., Yu, J. Z. (2014). Characterization of PM2.5 major components and source investigation in suburban Hong Kong: a one year monitoring study. Aerosol. Air Qual. Res. 14, 237-250. https://doi. org/10.4209/aaqr.2013.01.0020

Ianovici, N. (2008). Preliminary survey of airborne fungal spores in urban environment. Lucrări Științifice, seria Agronomie, USAMV IASI, 51(1), 84-89.

Klaric, S., \& Pepeljnjak, S. (2006). A year round aeromycological study in Zagreb area, Croatia. Annals of Agricultural and Environmental Medicine, 13, 55-64.

Lee, S. B., Milgroom, M. G., \& Taylor, J. W. (1998). A rapid, high yield mini-prep method for isolation of total genomic DNA from fungi. Fungal Genet Newsl, 35, 23-24.

Lin, W., \& Li, C. (2000a). Associations of fungal aerosols, air pollutants, and meteorological factors. Aerosol Sci Tech, 32, 359-368. 
Lin, W.-H., \& Li, C.-S. (2000b). Associations of fungal aerosols, air pollutants, and meteorological factors. Aerosol Science \& Technology, 32(4), 359368. https://doi.org/10.1080 /027868200303678.

Makut, M. D., Nyam, M. A., Shehu, L., \& Anzak, S. J. (2014). A survey of the microflora of the outdoor air environment of Keffi Metropolis, Nasarawa State, Nigeria. African Journal of Microbiology, 8(27), 2650-2655.

Mitakakis, T. Z., Clift, A., \& McGee, P. A. (2001). The effect of local cropping activities and weather on the airborne concentration of allergenic Alternaria spores in rural Australia. Grana, 40, 230-239.

Njokuocha, R. C. (2006). Airborne pollen grains in Nsukka, Nigeria. Grana, 45, 73-80.

Njokuocha, R. C., \& Ukeje, H. O. (2006). The study of airborne pollen precipitation in the University of Nigeria (Nsukka) botanic garden. Bio-Research., 4(2), 88-93.

Odebode, A. J. (2017). Characterization of allergenic fungal spores from selected locations in Lagos and Ibadan, Nigeria. $\mathrm{PhD}$ unpublished thesis, University of Lagos. $241 \mathrm{pp}$.

Pepeljnjak, S., \& Šegvić, M. (2003). Aerobiologia, 19, 11. https://doi.org/10.1023/A:1022693032075.

Peternel, R., Čulig, J., \& Hrga, I. (2004). Atmospheric concentrations of Cladosporium spp. and Alternaria spp. spores in
Zagreb (Croatia) and effects of some meteorological factors. Ann Agric Environ Med, 11, 303-307.

Rangaswamy, B. E., Francis, F., Prakash, K. K., \& Manjunath, N. S. (2013). Variability in airborne bacterial and fungal population in the tertiary health care centre. Aerobiologia, 29, 473-479.

Rossi, V., Bugiani, R., Giosué, S., \& Natali, P. (2005). Patterns of airborne conidia of Stemphylium vesicarium, the causal agent of brown spot disease of pears, in relation to weather conditions. Aerobiologia, 21, 203-216.

Sanchez, H., \& Bush, R. K. (2001). A review of Alternaria alternata sensitivity. Rev Iberoam Micol, 18(2), 56-59.

Tournas, V. H., \& Katsoudas, E. (2005). Mould and yeast flora in fresh berries, grapes and citrus fruit. International Journal of Food Microbiology, 105(1), 11-17. https://doi.org/10.1016/j. ijfoodmicro.2005.05.002.

Tsai, F. C. and Macher, J. M. (2005). Concentrations of airborne culturable bacteria in 100 large US office buildings from the base study. Indoor Air. 15:71-81.

Publisher's note Springer Nature remains neutral with regard to jurisdictional claims in published maps and institutional affiliations. 